\title{
Indirect diagnostic tests for the detection of subclinical mastitis in dairy goats experimentally infected with Staphylococcus aureus
}

\author{
Testes diagnósticos indiretos na deteç̧ão da mastite subclínica em \\ cabras leiteiras infectadas experimentalmente com Staphylococcus aureus
}

\author{
Rodolfo de Moraes Peixoto ${ }^{I^{*}}$ Renata de Moraes Peixoto Araújo ${ }^{I I}$ Luciana Jatobá e Silva Peixoto $^{\mathrm{I}}$ \\ Ariel Marques Reges ${ }^{I I}$ Ana Paula Pereira Alves ${ }^{I I}$ José Wilton Pinheiro Júnior ${ }^{I I I}$ \\ Rinaldo Aparecido Mota ${ }^{\text {III }}$ Sérgio Santos Azevedo ${ }^{\text {IV }}$ Mateus Matiuzzi da Costa ${ }^{\text {II }}$
}

ABSTRACT

The aim of the present study was to assess two diagnostic techniques (California mastitis test (CMT) and the somatic cell count (SCC)) that can diagnose mastitis in dairy goats. Experimental infection was conducted using 20 mammary glands, a strain of Staphylococcus aureus, an infectious dose of $1.2 \times 10^{8} \mathrm{CFU}$ $m L^{-1}$ and a volume of $1 m L$ per mammary gland. The CMT and the $S C C$ were used to detect subclinical mastitis. Bacterial culture (BC) was performed immediately after milk collection and was used as the gold standard. Four experimental time points were established $(0,24,48$ and 72 hours post-inoculation). Analysis of the ROC curve confirmed that the best combination of sensitivity and specificity were obtained with a cutoff point of 405.5, 6030.0 and $729.5 \times 10^{3}$ cells $m L^{-1}$, respectively at $M 1, M 2$ and $M 3$. Furthermore, considering the drop in sensitivity throughout the experimental time points, the use of serial bacterial cultures are recommended, particularly in herds with a high prevalence of $\boldsymbol{S}$. aureus.

Key words: bacterial culture, intramammary infection, small ruminant, somatic cell count.

\section{RESUMO}

Neste trabalho, objetivou-se avaliar duas técnicas diagnósticas (California mastitis test (CMT) e a contagem de células somáticas (CCS)) disponíveis para o diagnóstico da mastite em cabras leiteiras. Realizou-se infecção experimental em 20 metades mamárias, utilizando-se cepa de $\boldsymbol{S}$. aureus, em uma dose infectante de $1,2 \times 10^{8} \mathrm{UFC} \mathrm{mL}^{-1}$ e um volume de $1 \mathrm{~mL} /$ metade mamária. Para deteç̧ão da mastite subclínica, foi utilizado o CMT e a CCS. A cultura bacteriológica (CB) foi empregada como padrão ouro, sendo realizada logo após a coleta do leite. Foram estabelecidos quatro momentos experimentais (0, 24, 48 e 72 horas pós-infecção). A análise da curva de ROC confirmou que a melhor combinação (sensibilidade e especificidade) foi obtida com ponto

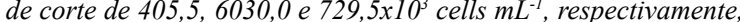
em M1, M2 and M3. Ademais, levando em consideração a queda da sensibilidade ao longo dos momentos experimentais, é relevante a realização da cultura bacteriológica seriada, principalmente em rebanhos com elevada prevalência de $\boldsymbol{S}$. aureus.

Palavras-chave: cultura bacteriológica, infecção intramamária, pequenos ruminantes, contagem de célula somática.

\section{INTRODUCTION}

Mastitis involves inflammation of the mammary gland and is usually caused by microorganims, notably bacteria. The most frequent isolates are $\boldsymbol{S}$. aureus, in clinical cases, and coagulasenegative species (CNS), in subclinical cases of intramammary infection (IMI) (BERGONIER et al., 2003). Control measures for $\boldsymbol{S}$. aureus mastitis are important in order to reduce economic losses and decrease the risk of diseases, being transmitted to humans via food (CORTIMIGLIA et al., 2015). For instance, these authors recorded a high prevalence of $\boldsymbol{S}$. aureus in herds of dairy goats by isolating methicillin-resistant strains (MRSA).

Although clinical mastitis exhibits low prevalence rates, the subclinical form exhibits high rates among goats and has been associated with high somatic cell counts. The somatic cell count (SCC) in

\footnotetext{
IInstituto Federal de Educação, Ciência e Tecnologia do Sertão Pernambucano (IF SERTÃO-PE), Campus Petrolina Zona Rural, BR 235, Km 22, Projeto Senador Nilo Coelho, N4, 56300-000, Petrolina, PE, Brasil. E-mail: rmpeixoto.vet@gmail.com. *Corresponding author.

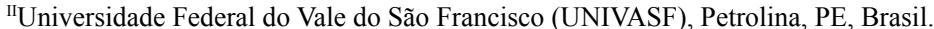

IIIDepartamento de Medicina Veterinária, Universidade Federal Rural de Pernambuco (UFRPE), Recife, PE, Brasil.

${ }^{\text {IV }}$ Centro de Saúde e Tecnologia Rural (CSTR), Universidade Federal de Campina Grande (UFCG), Patos, PB, Brasil.
} 
milk is the basis of mastitis control programs and milk quality control. Neutrophils are the main cell type in infected mammary glands (SOUZA et al., 2012).

Efficient dairy production should involve the examination of herds using tools that can effectively detect cases of subclinical mastitis. Although a bacteriological examination is regarded as the gold standard among tests to diagnosis mastitis, the isolation of the etiological agent in mastitis might not be possible for several reasons. Among these reasons there are: microorganisms excreted intermittently and in small amounts; infectionrelated pathogens not detectable using conventional microbiological tests; some milk enzymes or proteins (i.e., lysozymes and lactoferrin) that may thwart pathogen detection. There is also the infection that might be supported by bacterial endotoxins and bioactive compounds released by neutrophils that remain following the elimination of the invading bacteria (PYÖRÄLÄ, 2003; NUNES et al., 2008). Indirect tests are more suitable for the selection of animals with IMIs for subsequent bacteriological sampling. Thus, subclinical mastitis can go unnoticed unless additional diagnostic tools are used.

The aim of the present study was to assess the overall sensitivity and specificity of the techniques (CMT and SCC) available to diagnose mastitis in dairy goats that were experimentally infected with $S$. aureus.

\section{MATERIALS AND METHODS}

Ten female Saanen goats were used. All of the animals were aged between 1.5 and 4 years and were between the first and second parity. In total, 20 mammary glands were experimentally infected. Prior to the inoculation, the bacteriological and cellular characteristics of the milk were established. The animals were negative in three consecutive milk cultures, with intervals of seven days between collections (before challenged). Animals were between the sixth and ninth month of lactation, with a mean daily milk production of $0.98 \mathrm{~L}$ animal $^{-1}$ $(\mathrm{sd}=0.34)$ before inoculation and $0.90 \mathrm{~L}$ animal $^{-1}$ $(\mathrm{sd}=0.42)$ after inoculation. All females goats were serologically negative for caprine arthritisencephalitis virus by agar gel immunodiffusion (AGID) (Biovetech ${ }^{\circledR}$, Recife, Brazil) using the p28 as the antigen, and negative for Mycoplasma agalactiae in the PCR (LAUERMAN, 1998).

After obtaining the indices of the variables at the initial time point, the two halves of each female mammary gland were infected using the intramammary route and a number 4 urethral probe, coupled to a sterilized plastic syringe. Prior to inoculation, complete milking and antisepsis were carried out on both teats using $70 \%$ alcohol. After the inoculation $(1 \mathrm{~mL})$, a massage of upward movements were conducted in order to spread the inoculum throughout the mammary gland. A strain of $\boldsymbol{S}$. aureus was used at an infectious dose of $1.2 \times 10^{8} \mathrm{CFU} \mathrm{mL} \mathrm{mL}^{-1}$. This field strain was identified by its biochemical characteristics and taken from a case of subclinical goat mastitis. The following experimental time points were established: M0 (0h); M1 (24 hours postinoculation); M2 (48 hours post-inoculation) and M3 (72 hours post-inoculation).

Before and after experimental inoculation, the strip cup test and a clinical examination of the udder were performed to detect clinical mastitis (TYLER, 2002). The CMT was used to detect subclinical mastitis, as described in the literature (CONTRERAS et al., 1996). In order to determine the SCC, milk samples were collected, after discarding the first three milk streams, in flasks containing Bronopol, which were submitted to flow cytometry (SomaScope MKII, Delta Instruments, Wilmington, USA). The following values were considered as indicators of the disease: SCC: $>1 \times 10^{6}$ and CMT: $\geq 1+$ (SOUZA et al., 2012). In order to determine the total bacterial count (TBC), milk samples were also collected in flasks containing azidiol. The TBC was determined using automated equipment that depends on flow cytometry to count the bacteria in raw milk (Bactocount IBC, Bentley Instruments ${ }^{\circledR}$ ). The result was expressed in CFU $\mathrm{mL}^{-1} \times 10^{3}$.

Milk culture was performed according to the criteria established by OLIVER et al. (2004). Bacterial isolation was conducted using the milk collected before milking, after antisepsis of the teats with $70 \%$ alcohol. Milk was collected directly into sterile vials. Bacteria were identified according to their morphological, biochemical and staining characteristics. The following biochemical tests were used: coagulase; esculin; purple agar base (PAB); semi-solid glucose (GSS); semi-solid mannitol (MSS) and DNAse agar (QUINN et al., 1994). These were then placed in cooler boxes with ice and immediately sent to the Microbiology and Immunology Laboratory of the Universidade Federal do Vale do São Francisco (UNIVASF) for processing.

In order to assess the diagnostic tests (CMT and SCC), the result of the bacterial culture (BC) conducted on the same day as the remaining tests were used as gold standard. Thus, for each experimental time point, the result of the $\mathrm{BC}$ obtained at that exact moment was considered the 
gold standard. The positivity and negativity results in the $\mathrm{BC}$ at the end of the collections performed $(\mathrm{n}=3)$ defined the sanitary status of the animal. Thus, the CMT and SCC results obtained 72 hours (M3) after the experimental challenge were compared with the $\mathrm{BC}$ result at the end of the three consecutive samplings, made at intervals of 24 hours. The result obtained from the three collections was considered the gold standard. Sensitivity, specificity, positive and negative predictive values, accuracy and Kappa coefficient were also calculated. Kappa values above 0.7 indicated an excellent agreement, whereas values between 0.4 and 0.7 indicated a moderate/ satisfactory agreement. Values under 0.4 indicated a poor agreement. Receiver Operating Characteristic (ROC) curve analysis was used to obtain the best combination of sensitivity and specificity for the SCC and CMT tests at M1, M2 and M3.

The McNemar test was used to assess the degree of agreement between the diagnostic tests. Values obtained for the SCC and CFU at each experimental period were compared using the Friedman test. The Mann-Whitney test was used to compare the SCC values between the positive and negative samples in the $\mathrm{BC}$, with the level of significance set at $5 \%$.

After the logarithmic transformation, the non-normality of the data was confirmed by the Shapiro-Wilk test. Version 20.0 of the Statistical Package for the Social Sciences (SPSS) for Windows was used for the data analysis.

\section{RESULTS}

No clinical signs of mastitis were observed at the experimental time points assessed. The positivity rates recorded in the bacteriological milk culture were $55 \%, 45 \%$ and $5 \%$ for time points $\mathrm{M} 1$, M2 and M3, respectively (Table 1).

The SCC values at time points M1, M2 and M3 were higher than those obtained prior to the challenge with the $\boldsymbol{S}$. aureus strain $(\mathrm{P} \leq 0.05)$. No statistically significant differences were reported between the positive and negative samples in the $\mathrm{BC}$ at M1. Figure 1 displayed the dynamic between the SCC and TBC at all experimental time points. Significant differences $(\mathrm{P}<0,05)$ were recorded for both variables when comparing M0 with the other experimental time points, with a notably accentuated SCC at M2. The ROC curve analysis confirmed that the best combination of sensitivity and specificity was obtained while using a threshold of $405.5 \times 10^{3}$ cells $\mathrm{mL}^{-1}$, with values of $72.7 \%$ and $66.7 \%$, respectively, at M1. For $\mathrm{M} 2$, the best combination of sensitivity and specificity was obtained while using a threshold of $6030.0 \times 10^{3}$ cells $\mathrm{mL}^{-1}$, with values of $66.7 \%$ and $81.8 \%$. Seventytwo hours after the experimental infection, the best combination of sensitivity and specificity was obtained while using a threshold of $729.5 \times 10^{3}$ cells $\mathrm{mL}^{-1}$, with values of $100.0 \%$ and $15.8 \%$.

Tables 2 and 3 display the predictive values of SCC and CMT, respectively.

\section{DISCUSSION}

A high inoculum dose of Staphylococcus aureus was choosen when compared to other studies (LOPES et al., 2003; SHKRETA et al., 2004) due to the low virulence factors of the field bacteria strain used. The BCs performed at each time point were compared with the positivity results at the end of the series of cultures. S. aureus was not always isolated with frequency and there was a decrease in positivity over the course of the experimental time points. According

Table 1 - Bacterial culture (BC), California mastitis test (CMT) and somatic cell count (SCC) results for the milk of goats experimentally inoculated with Staphylococcus aureus.

\begin{tabular}{llllll}
\hline Time points & $\begin{array}{c}\text { BC } \\
\text { \% PS }\end{array}$ & CMT & \% PS & Median & MD $^{3}$ \\
\hline M0 & 0.0 & 0.0 & 0.0 & 66.0 & 144.8 \\
M1 & 55.0 & 50.0 & 40.0 & 55.0 & 5670.0 \\
M2 & 45.0 & 70.0 & 80.0 & 4087.0 & 6877.6 \\
M3 & 5.0 & 65.0 & 70.0 & 2502.0 & 5593.5 \\
Serial $^{1}$ & 75.0 & 80.0 & 80.0 & - & - \\
\hline
\end{tabular}

M0: before infection; M1: 24 hours post-inoculation; M2: 48 hours post-inoculation; M3: 72 hours post-inoculation. SCC values expressed as $10^{3}$ cells/mL. Positivity was considered when: SCC: $>1 \times 10^{6}$ cells $/ \mathrm{mL}$ and CMT: $\geq 1+($ SOUZA et al., 2012).

${ }^{1}$ Serial culture positive (\%); ${ }^{2}$ Positive samples; ${ }^{3}$ Measure of dispersion (interquartile range). 


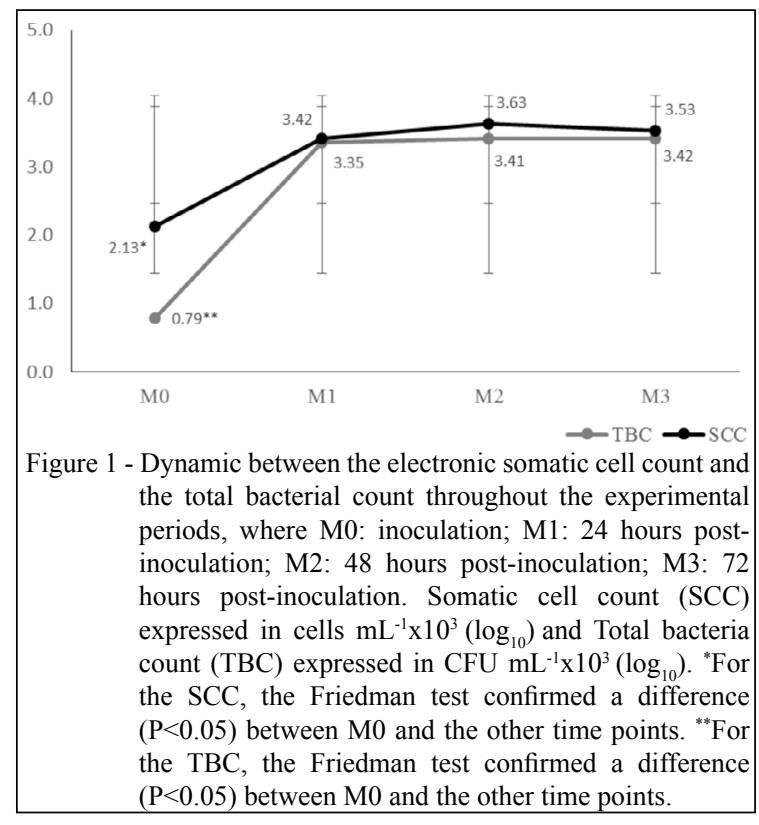

to OLIVER et al. (2004), the isolation of $\boldsymbol{S}$. aureus in milk samples is considered definitive for a diagnosis of IMI by the pathogen. However, intermittent excretion of this pathogen in milk (BERGONIER et al., 2003) could explain the false-negative results in some cases. Furthermore, PETZL et al. (2008) noted that cattle with a high SCC 12 hours after the experimental infection exhibit low levels of reisolation, suggesting that the bacteria are eliminated very quickly when there is a strong influx of neutrophilic granulocytes. When analyzing experimental infections with Escherichia coli and $\boldsymbol{S}$. aureus, the same authors recorded a lower rate of recovery for $\boldsymbol{S}$. aureus, suggesting a slower rate of multiplication for this pathogen in the udder, when compared with $\boldsymbol{E}$. Coli.
Most of the samples that were positive in the $\mathrm{BC}$ exhibited "traces" and 1+ reactions in the CMT, thereby demonstrating the importance of considering these reactions when monitoring mastitis in herds of dairy goats with a high prevalence of $\boldsymbol{S}$. aureus. Thus, the CMT is a valuable tool in the determination of the presence of subclinical mastitis (SOUZA et al., 2012).

The median SCC values did not exhibit any statistically significant differences between the positive and negative samples in the BC at M1. At M2 however, the SCC values were higher in the positive samples in the $\mathrm{BC}(\mathrm{P} \leq 0.05)$. LEITNER et al. (2011) studied systemic and local mammary gland immunity for udder infections in goats, using several Staphylococcus species, and confirmed that the SCC and total leukocyte counts were significantly higher in infected glands than in uninfected glands, with the highest SCC recorded in milk from glands infected with Staphylococcus aureus. KOOP et al. (2012) also reported a higher cell count in infected mammary glands, noting that this count was higher in glands infected by $\boldsymbol{S}$. aureus than it was in glands infected by CNS.

Analysis of the ROC curve confirmed that the best combination of sensitivity and specificity was obtained when the cut-off point was $850 \times 10^{3}$ cells $\mathrm{mL}^{-1}$. These results showed the importance of several factors that affected the elevation of the SCC. The SCC has been widely used to assess the inflammatory status of the mammary glands of goats and sheep. LUENGO et al. (2004) noted that multiple births and short-duration lactation were associated with an elevated SCC in milk. SOUZA et al. (2012) provided a list of several factors that can affect the SCC of uninfected goats, such as: lactation stage; seasonality; milk production; numbers of kids; milking frequency and the use of machine milking or hand milking. It is essential that technicians

Table 2 - Analysis of the somatic cell count values in comparison with each bacterial culture and with positivity at the end of serial culture.

\begin{tabular}{|c|c|c|c|c|}
\hline \multirow{2}{*}{ Values observed } & \multicolumn{4}{|c|}{--Somatic cell count--- } \\
\hline & M1 & M2 & M3 & $\mathrm{SC}$ \\
\hline Sensitivity (\%) & 45.5 & 100.0 & 0.0 & 86.7 \\
\hline Specificity (\%) & 66.7 & 36.4 & 26.3 & 80.0 \\
\hline+ predictive value $(\%)$ & 62.5 & 56.3 & 0.0 & 92.9 \\
\hline - predictive value (\%) & 50.0 & 100.0 & 83.3 & 66.7 \\
\hline Accuracy $(\%)$ & 55.0 & 65.0 & 25.0 & 85.0 \\
\hline Kappa & 0.12 & 0.34 & -0.10 & 0.63 \\
\hline McNemar & NS & $=0.05$ & $=0.05$ & NS \\
\hline
\end{tabular}

M1: 24 hours post-inoculation; M2: 48 hours post-inoculation; M3: 72 hours post-inoculation; SC: serial culture. The gold standard was considered the bacterial culture performed at each experimental moment, as well as the positivity at the end of the three collections. Positivity was considered when: SCC: $>1 \times 10^{6}$ cells $/ \mathrm{mL}$. McNemar test with $p \leq 0.05$ indicates a disagreement between the result obtained at the experimental time point and the result of the serial culture. NS: not statistical significant. 
Table 3 - Analysis of the results of the California mastitis test (CMT) in comparison with the bacterial culture (BC) performed at each experimental time point.

\begin{tabular}{|c|c|c|c|c|c|c|c|c|}
\hline \multirow{2}{*}{ Values observed } & \multicolumn{4}{|c|}{ - } & \multicolumn{4}{|c|}{ 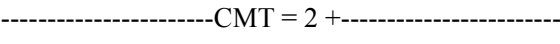 } \\
\hline & M1 & M2 & M3 & $\mathrm{SC}$ & M1 & M2 & M3 & $\mathrm{SC}$ \\
\hline Sensitivity $(\%)$ & 54.5 & 88.9 & 0.0 & 80.0 & 27.3 & 44.4 & 0.0 & 26.7 \\
\hline Specificity (\%) & 55.6 & 45.5 & 31.6 & 80.0 & 88.9 & 81.8 & 78.9 & 100.0 \\
\hline+ predictive value $(\%)$ & 60.0 & 57.1 & 0.0 & 92.3 & 75.0 & 66.7 & 0.0 & 100.0 \\
\hline - predictive value $(\%)$ & 50.0 & 83.3 & 85.7 & 57.1 & 50.0 & 64.3 & 93.8 & 31.3 \\
\hline Accuracy (\%) & 55.0 & 65.0 & 30.0 & 80.0 & 55.0 & 65.0 & 75.0 & 45.0 \\
\hline Kappa & 0.10 & 0.33 & -0.10 & 0.53 & 0.15 & 0.27 & -0.09 & 0.15 \\
\hline McNemar & NS & NS & $=0.05$ & NS & $=0.05$ & NS & NS & $=0.05$ \\
\hline
\end{tabular}

M1: 24 hours post-inoculation; M2: 48 hours post-inoculation; M3: 72 hours post-inoculation; SC: serial culture. The gold standard was considered the BC performed at each experimental time point, as well as the positivity at the end of the three collections. Positivity was considered when: CMT: $\geq 1+$. McNemar test with $\mathrm{p} \leq 0.05$ indicated a disagreement between the result obtained at the experimental time point and the result of the serial culture. SC: serial culture. The serial culture involves the performance of three lacto cultures at intervals of 24 hours. NS: not statistically significant.

in the dairy sector use criteria that are consistent with local characteristics when determining the threshold of the SCC in screening tests for the detection of mastitis.

Many studies have addressed the SCC values of goats. However, given the specificities of the present study, comparisons should be made with caution. In cross-sectional studies seeking to detect naturallyacquired mastitis, a number of variables cannot be controlled, including the species of the pathogen, the period of exposure and the infective dose. Thus, it was decided to use an experimental infection model, thereby controlling certain important variables for the validation of diagnostic tests.

In the present study, the SCC peaked at M2 and was followed by a significant decrease of positive samples in the bacteriological culture. This suggests a bacteriological cure of the infected mammary gland, given that bacteriological cures greatly effect the SCC (SANCHEZ-PINZÓN \& RUEGG, 2011). This could explain the differences among the predictive values in the moments evaluated here. In addition, the low sensitivity of the test at M3 also corroborates the bacteriological cure after the peak of the SCC.

Considering the $\mathrm{BC}$ performed at M1, $\mathrm{M} 2$ and M3, the agreement analysis conducted using the SCC confirmed that the best overall sensitivity and specificity occurred 48 hours after the infection (M2). When the serial BC at the end of 72 hours was considered the gold standard, the accuracy of the SCC was higher $(85 \%)$. According to the literature, for $\boldsymbol{S}$. aureus samples that exhibited growth in only one colony, the sensitivity of the $\mathrm{BC}$ is greater than $90 \%$, which gradually decreases when higher cutoff points are established. However, for the SCC, the study indicated the maintenance of a cutoff point close to those recommended by different authors $\left(1 \times 10^{6}\right.$ cells $\left.\mathrm{mL}^{-1}\right)$. In all probability, the low cutoff point observed at M1 occurred because the increased SCC was mainly due to the influx of leukocytes from the blood to the inflammatory site, which requires a certain amount of time.

\section{CONCLUSION}

Given that the screening tests exhibited satisfactory sensitivity and specificity with cutoff points close to those recommended by other researchers, it is suggested that this threshold $\left(>1 \times 10^{6}\right.$ cells $\mathrm{mL}^{-1}$ ) should continue to be considered in goat milk production systems. Conversely, considering the drop in sensitivity (CB) throughout the experimental time points, serial bacterial cultures should be used (whenever possible), particularly in herds of dairy goats with a high prevalence of $\boldsymbol{S}$. aureus.

\section{ACKNOWLEDGMENTS}

The present study was financed by the Fundação de Amparo à Ciência e Tecnologia do Estado de Pernambuco (FACEPE) and the MCT-INSA/CNPq/CT-Hidro/Ação Transversal (No. 35/2010).

\section{BIOETHICS AND BIOSSECURITY COMMITTE APPROVAL}

The present study received approval from the Ethics Committee for Human and Animal Research in the Universidade Federal do Vale do São Francisco (UNIVASF) under protocol number $0005 / 131211$. 


\section{REFERENCES}

BERGONIER, D. et al. Mastitis of dairy small ruminants. Veterinary Research, v.34, p.689-716, 2003. Available from: $<$ http://www.vetres.org/articles/vetres/pdf/2003/05/V3511.pdf $>$. Accessed: Jun. 26, 2015. doi: 10.1051/vetres:2003030.

CONTRERAS, A. et al. Physiological threshold of somatic cell count and California Mastitis Test for diagnosis of caprine subclinical mastitis. Small Ruminant Research, v.21, p.259-264, 1996. Available from: <http://www.sciencedirect.com/science/ article/pii/0921448895008276>. Accessed: Apr. 20, 2014. doi: 10.1016/0921-4488(95)00827-6.

CORTIMIGLIA, C. et. al. Short communication: Prevalence of Staphylococcus aureus and methicillin-resistant $\boldsymbol{S}$. aureus in bulk tank milk from dairy goat farms in Northern Italy. Journal of Dairy Science, v.98, p.2307-2311, 2015. Available from: <http:// www.ncbi.nlm.nih.gov/pubmed/25648812>. Accessed: Jun. 26, 2015. doi: $10.3168 /$ jds.2014-8923.

KOOP, G. et al. Differences between coagulase-negative Staphylococcus species in persistence and in effect on somatic cell count and milk yield in dairy goats. Journal of Dairy Science, v.95, p.5075-5084, 2012. Available from: $<$ http://dx.doi. org/10.3168/jds.2012-5615>. Accessed: Apr. 22, 2014 . doi: $10.3168 /$ jds.2012-5615.

LAUERMAN, L.H. Mycoplasma PCR assays. In: LAUERMAN L.H. (Ed.). Nucleic acid amplification assays for diagnosis of animal diseases. Turlock, CA: American Association of Veterinary Laboratory Diagnosticians, 1998. p.41-42.

LEITNER, G. et al. Systemic and local mammary gland immunity to udder infection in goats by various Staphylococcus species. Small Ruminant Research, v.95, p.160-167, 2011. Available from: $<$ http://www.sciencedirect.com/science/article/pii/ S0921448810002671\#>. Accessed: Jun. 27, 2015. doi: 10.1016/j. smallrumres.2010.09.007.

LOPES, S.T.A. et al. Neutrophilic function activity in goats with mastitis experimentally induced by Staphylococcus aureus and supplemented with vitamin E (acetate DL-a-tocopherol). Arquivo Brasileiro de Medicina Veterinária e Zootecnia, v.55, p.515521, 2003. Available from: <http://dx.doi.org/10.1590/S010209352003000500001>. Accessed: Jan. 24, 2016.

LUENGO, C. et al. Influence of intramammary infection and noninfection factors on somatic cell counts in dairy goats. Journal of
Dairy Science, v.71, p.169-174, 2004. Available from: <http://www. ncbi.nlm.nih.gov/pubmed/15190944>. Accessed: Jun. 27, 2015.

NUNES, G.R. et al. Avaliação de indicadores inflamatórios no diagnóstico da mamite ovina. Arquivos do Instituto Biológico, v.75, p.271-278, 2008. Available from: <http://www.biologico. sp.gov.br/docs/arq/v75_3/nunes.pdf>. Accessed: Sept. 04, 2015.

OLIVER, S.P. et al. Microbiological procedures for the diagnosis of bovine udder infetion and determination of milk quality. In: NATIONAL MASTITIS COUNCIL, 4., 2004, Verona, WL. Proceedings... Verona: National Mastitis Council, 2004.

PETZL, W. et al. Escherichia coli, but not Staphylococcus aureus triggers an early increased expression of factors contributing to the innate immune defense in the udder of the cow. Veterinary Research, v.39, p.1-23, 2008. Available from: $<$ http://www.vetres. org/articles/vetres/pdf/2008/02/v07188.pdf>. Accessed: Jun. 26, 2015. doi: $10.1051 /$ vetres: 2007057 .

PINZÓN-SÁNCHEZ, C.; RUEGG, P.L. Risk factors associated with short-term post-treatment outcomes of clinical mastitis. Journal of Dairy Science, v.94, p.3397-3410, 2011. Available from: <http://http://www.journalofdairyscience.org/article/S00220302(11)00333-X/pdf>. Accessed: Sept. 22, 2015. doi: 10.3168/ jds.2010-3925.

PYÖRÄLÄ, S. Indicators of inflammation in the diagnosis of mastitis. Veterinary Research, v.34, p.565-578, 2003. Available from: <http://www.vetres.org/articles/vetres/pdf/2003/05/V3511. pdf>. Accessed: Jun. 26, 2015. doi: 10.1051/vetres:2003030.

QUINN, P.J. et al. Clinical veterinary microbiology. London: Wolf, 1994. 648p.

SHKRETA, L. et al. Immune response to a DNA/protein vaccination strategy against Staphylococcus aureus induced mastitis in dairy cows. Vaccine, v.23, p.114-126, 2004. Available from: $<$ http://www. ncbi.nlm.nih.gov/pubmed/15519714>. Accessed: Jan. 24, 2016.

SOUZA, F.N. et al. Somatic cell count in small ruminants: friend or foe? Small Ruminant Research, v.107, p.65-75, 2012. Available from: $<$ http://www.sciencedirect.com/science/article/pii/ S0921448812001538>. Accessed: Apr. 22, 2014. doi: 10.1016/j. smallrumres.2012.04.005.

TYLER, J.W. Exame clínico das glândulas mamárias. In: RADOSTITS, O.M. et al. Exame clínico e diagnóstico em veterinária. Rio de Janeiro: Guanabara Koogan, 2002. p.572-578. 